\title{
STUDY OF INCIDENCE OF HELICOBACTER PYLORI IN CASES OF DUODENAL ULCER PERFORATION IN GOVERNMENT VELLORE MEDICAL COLLEGE
}

\author{
K. Shantha Kumar ${ }^{1}$
}

${ }^{1}$ Associate Professor, Department of General Surgery, Government Vellore Medical College \& Hospital.

ABSTRACT
BACKGROUND
Most of the patients having chronic peptic ulcer disease are usually found to be infected with Helicobacter pylori infection.
Previously, when the ulcer goes for perforation, immediate acid reduction surgery was being done as there was a high incidence of
relapse of ulcers after a simple closure. But, since most of the ulcers are caused by H. pylori, eradication of these organisms reduces
the recurrence of ulcers.
the recurrence of ulcers.

The aim of our study was to study the incidence of Helicobacter pylori in cases of duodenal ulcer perforation.

\section{MATERIALS AND METHODS}

Our study included 30 operated patients of duodenal ulcer perforation and the incidence of H. pylori was found from the biopsy taken from ulcer edge, using Rapid urease test \& HPE.

\section{RESULTS}

Among thirty patients, samples of 16 patients (53.3\%) showed positive for Helicobacter pylori in Rapid urease test (CLO test) and HPE. The $p$ value calculated is $<0.05$ which is found to be significant by chi square test.

\section{CONCLUSION}

As Helicobacter pylori is the most common cause for duodenal ulcer perforation, anti-Helicobacter pylori eradication regimen can be used in all cases of perforated duodenal ulcer to prevent the ulcer recurrence and to prevent acid reducing surgeries.

\section{KEYWORDS}

Duodenal Ulcer Perforation, H. pylori, Perforation.

HOW TO CITE THIS ARTICLE: Kumar KS. Study of incidence of Helicobacter pylori in cases of duodenal ulcer perforation in Government Vellore Medical College. J. Evolution Med. Dent. Sci. 2016;5(103):7599-7604, DOI: 10.14260/Jemds/2016/1718
BACKGROUND
Previously, the researches done on 'Duodenal ulcer' mainly concentrated on the abnormalities in the secretion of acids. Most of them found that all duodenal ulcer patients have raised maximal acid output (MAO), in response to histamine or pentagastrin, showing a greater parietal cell mass (Blair and others 1987). Also, the acid secretion physiology is abnormal. Basal acid is raised to greater extent, which is identified from the increase in MAO. Researches done on hormonal control mainly concentrated on Gastrin, an antral acid stimulating hormone.[1] Research showed that gastric acid inhibition by intragastric acid is decreased in the duodenal ulcer patients (Calam \& Moss 1992). An important mediator named somatostatin inhibits gastric acid, also inhibits immune reactive somatostatin cells.[2] In patients with duodenal ulcer, amount of somatostatin peptide present in gastric antral mucosa are reduced (McHenry Jr et al 1993). Normally, the gastrin release is inhibited by intragastric acid.[3][4] This mechanism is altered in patients infected with Helicobacter
duodenal ulcer patients increases somatostatin RNA by about two folds in antral and duodenal mucosa, but not in corpus biopsies, this reflects typical distribution of involvement of mucosa in patients with duodenal ulcer. The realisation that Helicobacter Pylori may have a fundamental role in the aetiology \& the pathogenesis of peptic ulcer has led to therapeutic strategies aimed at eradicating this bacterium and curing the disease. Perforated peptic ulcer is approximately 7 to 10 cases per 100000 population per year. Perforation is present in about $7 \%$ of patients admitted in hospital for peptic ulcer disease. Also it is the first manifestation of the disease in about $2 \%$ of duodenal ulcer patients. Whether, the eradication of $\mathrm{H}$. pylori will reduce this complication has led many investigators to find out the presence of Helicobacter pylori in duodenal ulcer perforation. The present study is done to find out the incidence of Helicobacter pylori in duodenal ulcer perforation, making use of RUT and Giemsa staining as the previous studies quoted did not have the advantage of a definite and sensitive staining method to detect $\mathrm{H}$. pylori. pylori causing duodenal ulcer. Eradication of $\mathrm{H}$. pylori from

Financial or Other, Competing Interest: None.

Submission 08-10-2016, Peer Review 20-10-2016,

Acceptance 24-10-2016, Published 26-12-2016.

Corresponding Author:

Dr. K. Shantha Kumar,

Associate Professor,

Department of General Surgery,

Government Vellore Medical College \& Hospital.

E-mail:drkskumarmmc@gmail.com

DOI: $10.14260 /$ jemds $/ 2016 / 1718$

\section{Aim of Study \\ To study the incidence of Helicobacter pylori in cases of duodenal ulcer perforation in Government Vellore Medical College \& Hospital.}

\section{MATERIALS AND METHODS}

Thirty patients who underwent surgery for perforated duodenal ulcer on emergency basis in the Department of General Surgery in Government Vellore Medical College from August 2014 to July 2015 were included in this study. 
Inclusion criteria: 1) Patients between 18-70 years of age. 2) Patients having perforated duodenal ulcers.

Exclusion criteria: 1) Patients below 18 years and above 70 years of age. 2) Patients on NSAIDs for more than one month duration. 3) Patients who have received Anti-Helicobacter pylori treatment. 4) Patients with gastric ulcers or ulceroproliferative growth.

The study population consisted of 30 patients between age group of 18 - 55 yrs. Exploratory laparotomy was performed in all cases. Two mucosal biopsies were taken through the perforation site. One specimen is immediately put into a preformed $\mathrm{H}$. pylori 44 detection kit for rapid urease test (RUT), which shows the presence of urease producing bacteria by a change in the colour of the medium within a time frame which is read as follows: 1 . If a pink colour develops within 30 min. the test is taken as strongly positive. 2 . If a pink colour is not developed within half an hour but develops within two hours, then the test is moderately positive. 3 . If a pink colour is not developed within two hours but develops within 24 hours, then the test is weakly positive. 4. If a pink colour is not developed at the end of 24 hours, then the test is negative for H. pylori. The second biopsy specimen is fixed in $10 \%$ formalin solution and subjected to Genta staining in the department of pathology. This is a novel staining procedure that allows the unencumbered observation of the histopathologic characteristics of the tissue while optimally demonstrating $\mathrm{H}$. pylori. Formalin fixed duodenal specimen is processed, cut into 4 micrometre sections and placed on regular microscopic slides. To melt the paraffin, slides are dried in an oven at $60^{\circ}$ centigrade for $15 \mathrm{~min}$. followed by microwaving for $3 \mathrm{~min}$. Slides are then stained according to the following procedure: 1. Deparaffinise the sections and rehydrate the sections in distilled water. 2 . Sensitisation of sections is done by placing them in $1 \%$ aqueous uranyl nitrate at room temperature for three minutes, followed by transferring them to distilled water. 3. Rinse slides in distilled water thoroughly as there is chance for cross contamination. 4. Keep the section in $1 \%$ AgNO3 (silver nitrate) at room temperature and then heat them together. 5. The microwave oven should be set up to heat below boiling point. 6 . Rinse slides for three times in distilled water until the chance of contamination is eliminated. 7. Rinse it two times in $95 \%$ alcohol. 8. Rinse it two times in $100 \%$ alcohol. 9. Keep the slides in $2.5 \%$ gum acacia for $5 \mathrm{~min}$. 10 . Air drying of sections is done for $1 \mathrm{~min}$. 11. Rinse it two times in distilled water. 12 . Reduce it in the reducing solution, in a $45^{0}$ centigrade water bath for 10-15 min. or until the sections have developed a dark brown H. pylori. 13. Rinse the sections in water to stop reduction. 14. Stain in Alcian blue with $\mathrm{pH} 2.5$ for 10 min. 15. Rinse the slide in running tap water. 16 . Stain the sections in haematoxylin for $5 \mathrm{~min}$. 17. Rinse it in running tap water. 18. Quickly dip the slide in acid alcohol. 19. Rinse it in ammonia water $0.25 \%$ until it turns blue. 20 . Stain the sections in eosin for $5 \mathrm{~min}$. 21. Quickly rinse in tap water. 22. Rinse the slide twice in $95 \%$ alcohol. 23 . Rinse it three times in absolute alcohol. 24. Rinse it three times in xylene and place the coverslip and examine under microscope. Reducing solution: $10 \mathrm{~mL}$ of $2.5 \%$ gum acacia, $25 \mathrm{~mL}$ of $2 \%$ hydroquinone, $5 \mathrm{~mL}$ of absolute alcohol and $2.5 \mathrm{~mL}$ of $0.04 \%$ silver nitrate, unfiltered.

\section{Statistical Analysis}

Descriptive results were expressed as mean, SD and percentages, qualitative variables were assessed using chi square test. Probability value ( $p$ value) was used to determine the level of significance, $p$ value $<0.05$ was considered as significant, $\mathrm{p}$ value $<0.01$ was considered as highly significant.

\section{RESULTS AND OBSERVATIONS}

A prospective study for determining the incidence of $\mathrm{H}$. pylori in a perforated duodenal ulcer is carried out. The following observations are made: The mean age of the patient is $44.6 \mathrm{yrs}$. All the patients were male. $83 \%$ are smokers (25 of 30 patients). $5(16.6 \%)$ were addicted to pan chewing and 3 $(10 \%)$ were in the habit of gutkha chewing. 17 (56.6\%) of 30 patients had past history of pain abdomen, more in the epigastrium relived by taking antacids $/ \mathrm{H}_{2}$ blockers. 16 (53.3\%) of 30 patients had history of NSAID abuse. Two patients $(6.6 \%)$ were on steroids. $16(53.3 \%)$ of 30 patients whose mucosal biopsy was subjected to rapid urease test (RUT), tested positive for urease (10 strongly positive and 6 moderately positive), 14 (46.7\%) tested negative for RUT. 16 of the 30 patients (53.3\%) whose mucosal biopsy was specially investigated for $\mathrm{H}$. pylori by Genta tested positive for the bacteria.

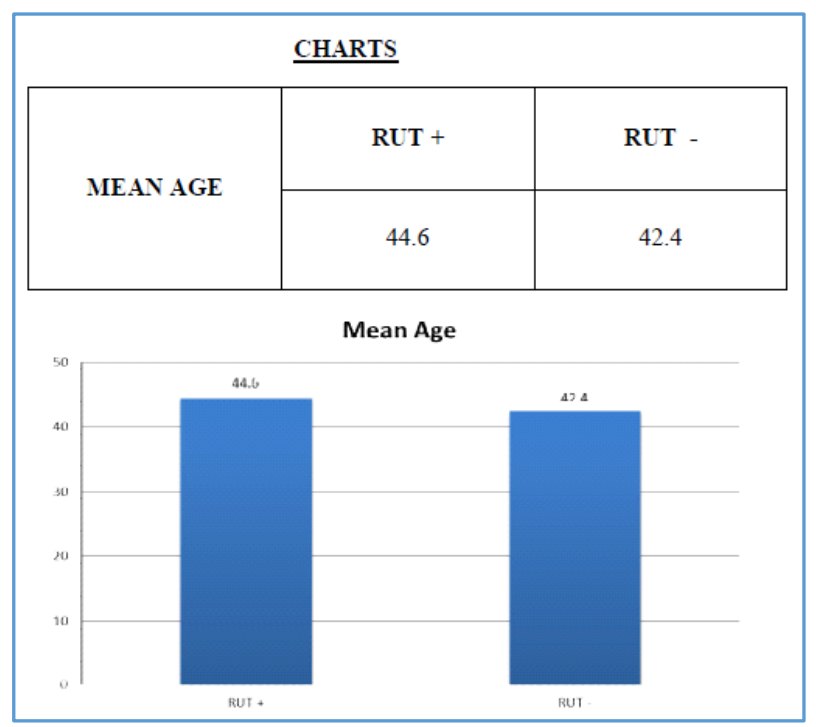




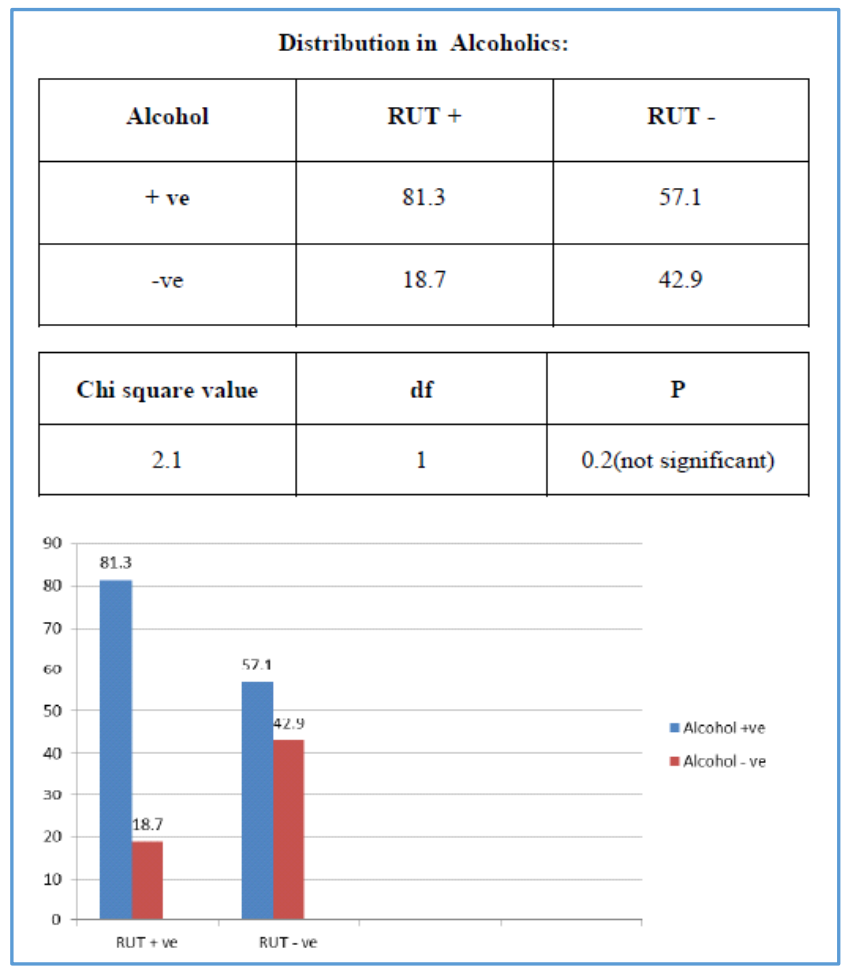

\begin{tabular}{|c|c|c|c|}
\hline \multicolumn{4}{|c|}{ Distribution in Smokers: } \\
\hline & Smoking & RUT + & RUT - \\
\hline & + ve & 87.5 & 78.6 \\
\hline & -ve & 12.5 & 21.4 \\
\hline \multicolumn{2}{|c|}{ Chi square value } & df & $\mathbf{P}$ \\
\hline \multicolumn{2}{|r|}{0.4} & 1 & 0.5 (not significant) \\
\hline \multicolumn{3}{|l|}{100} & \multirow{9}{*}{$\begin{array}{l}\text { "Smoking +ve } \\
\text { "Smoking - ve }\end{array}$} \\
\hline${ }_{80}^{90}$ & \multicolumn{2}{|l|}{87.5} & \\
\hline 70 & & & \\
\hline \multirow{2}{*}{60} & & & \\
\hline & & & \\
\hline $\begin{array}{l}50 \\
40\end{array}$ & & & \\
\hline $30-$ & & & \\
\hline 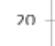 & 12.5 & & \\
\hline $\begin{array}{r}10-7 \\
0\end{array}$ & & & \\
\hline & RUT + ve & & \\
\hline
\end{tabular}

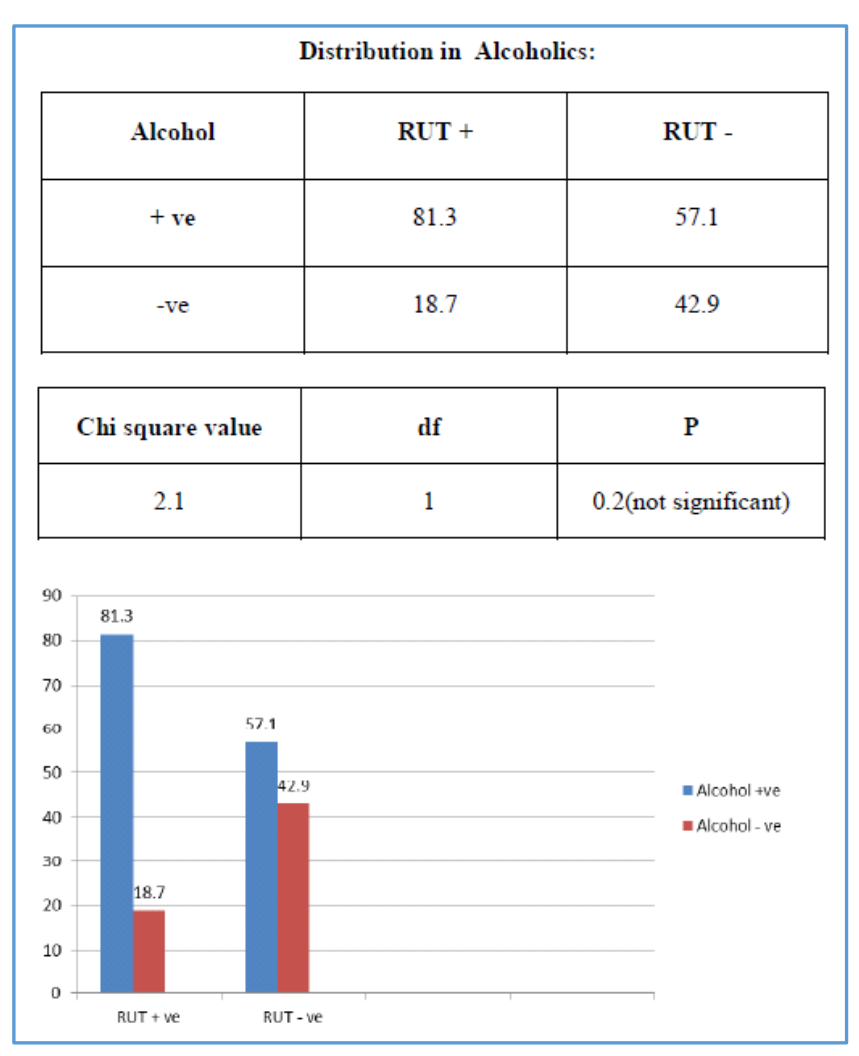

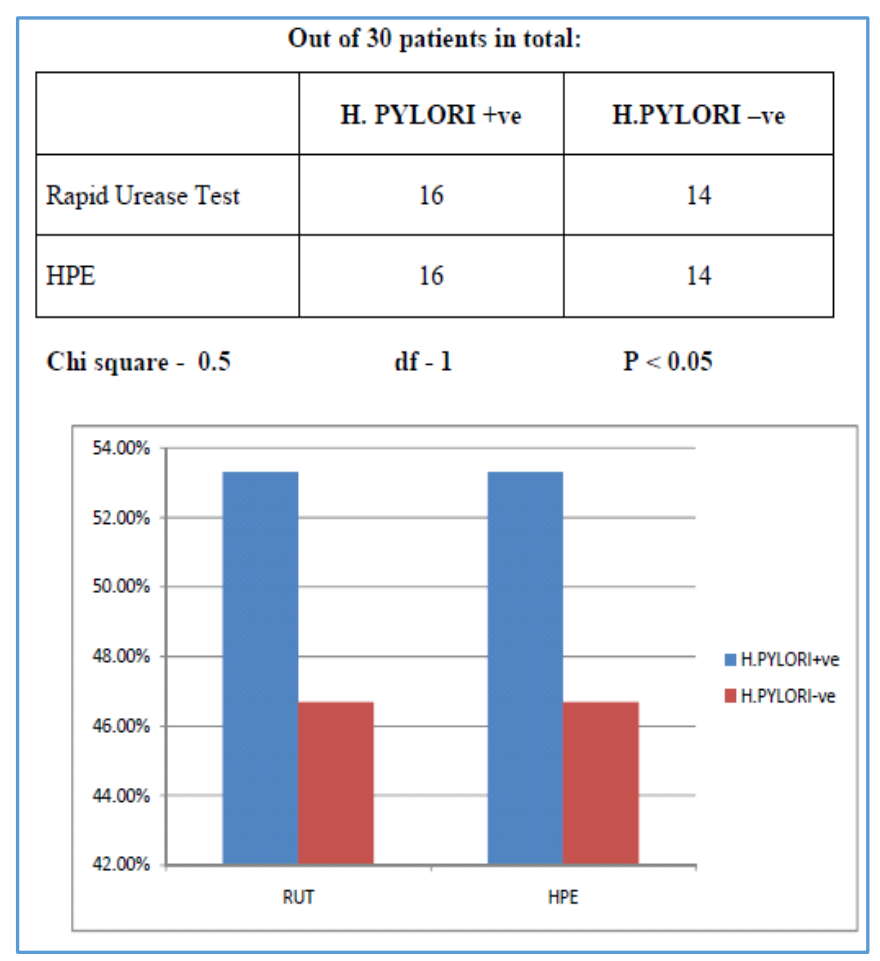




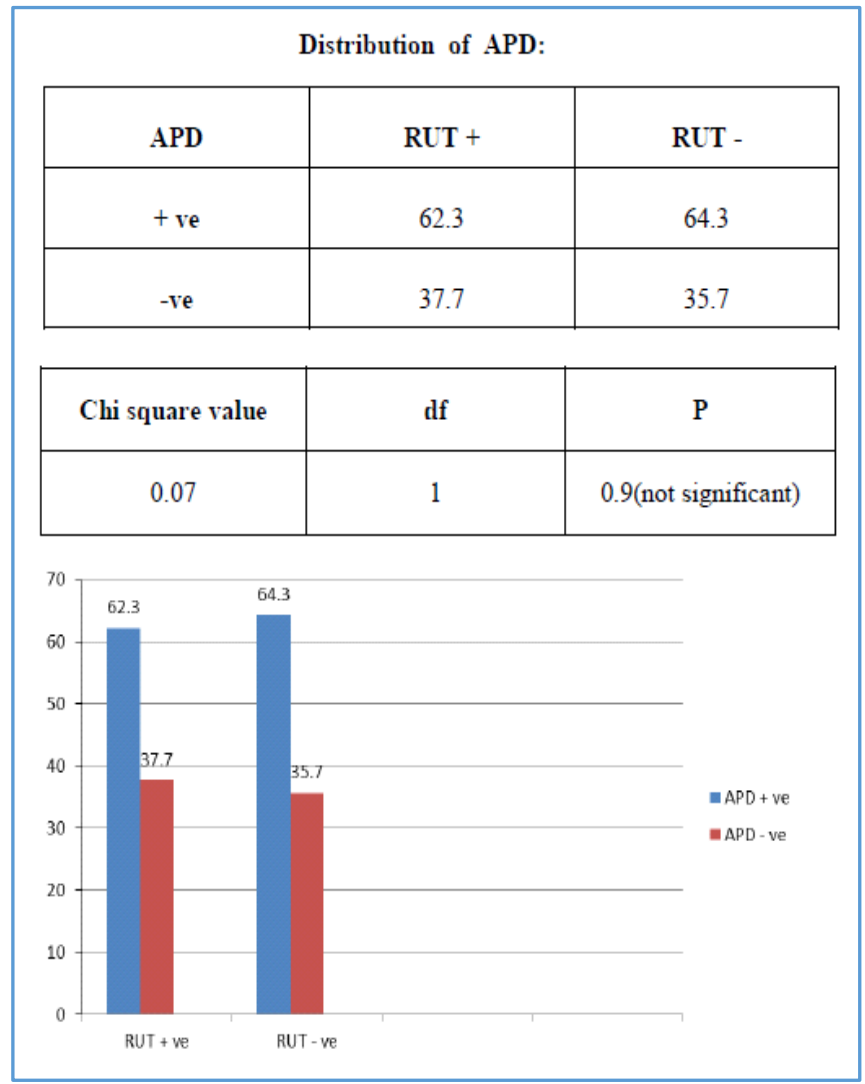

\begin{tabular}{|c|c|c|}
\hline \multicolumn{3}{|c|}{ Distribution in Antibiotic users: } \\
\hline ANTIBIOTIC & RUT + & RUT - \\
\hline+ ve & 12.5 & 21.4 \\
\hline -ve & 87.5 & 78.6 \\
\hline
\end{tabular}

\begin{tabular}{|c|c|c|}
\hline Chi square value & df & P \\
\hline 0.4 & 1 & 0.5 \\
\hline
\end{tabular}

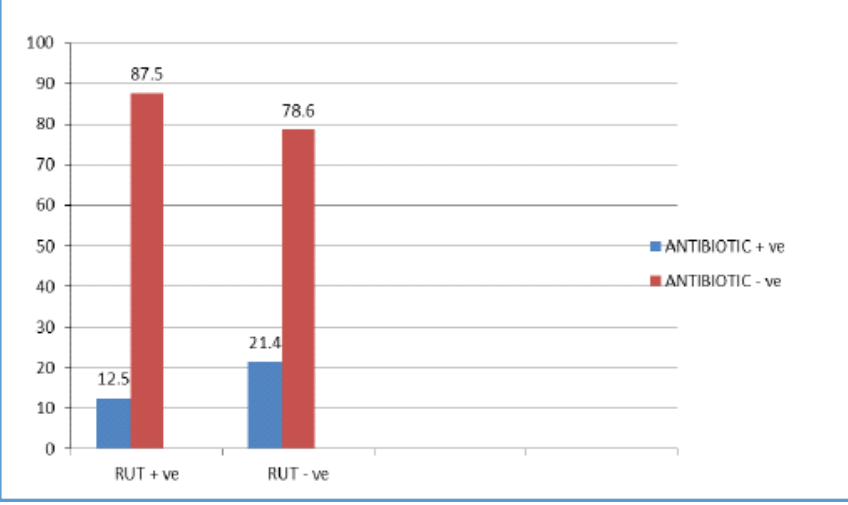

\begin{tabular}{|c|c|c|}
\hline \multicolumn{3}{|c|}{ Distribution of NSAIDs: } \\
\hline NSAID & RUT + & RUT - \\
\hline+ ve & 62.3 & 42.9 \\
\hline -ve & 37.7 & 57.1 \\
\hline
\end{tabular}

\begin{tabular}{|c|c|c|}
\hline Chi square value & df & P \\
\hline 1.2 & 1 & 0.3 \\
\hline
\end{tabular}

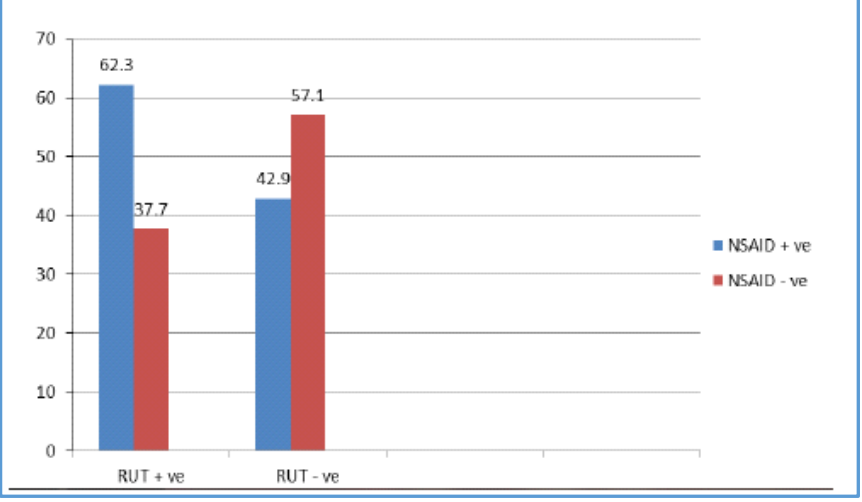

\begin{tabular}{|c|c|c|}
\hline \multicolumn{3}{|c|}{ Distribution in Antibiotic users: } \\
\hline ANTIBIOTIC & RUT + & RUT - \\
\hline + ve & 12.5 & 21.4 \\
\hline -ve & 87.5 & 78.6 \\
\hline
\end{tabular}

\begin{tabular}{|c|c|c|}
\hline Chi square value & df & $\mathbf{P}$ \\
\hline 0.4 & 1 & 0.5 \\
\hline
\end{tabular}

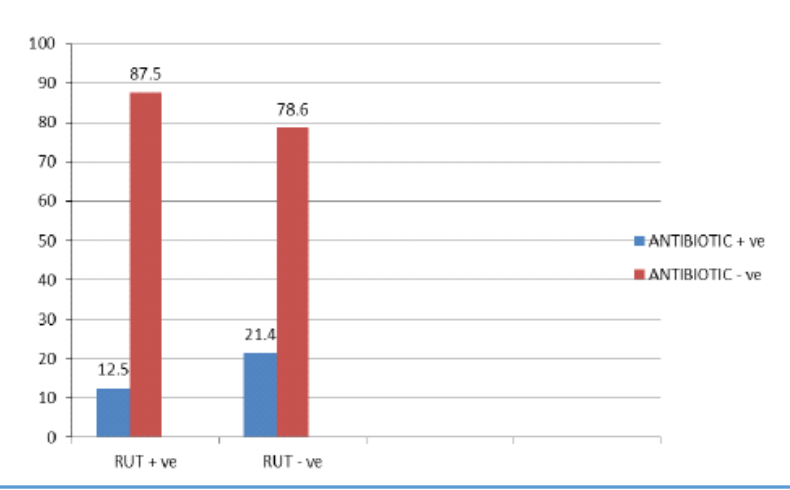




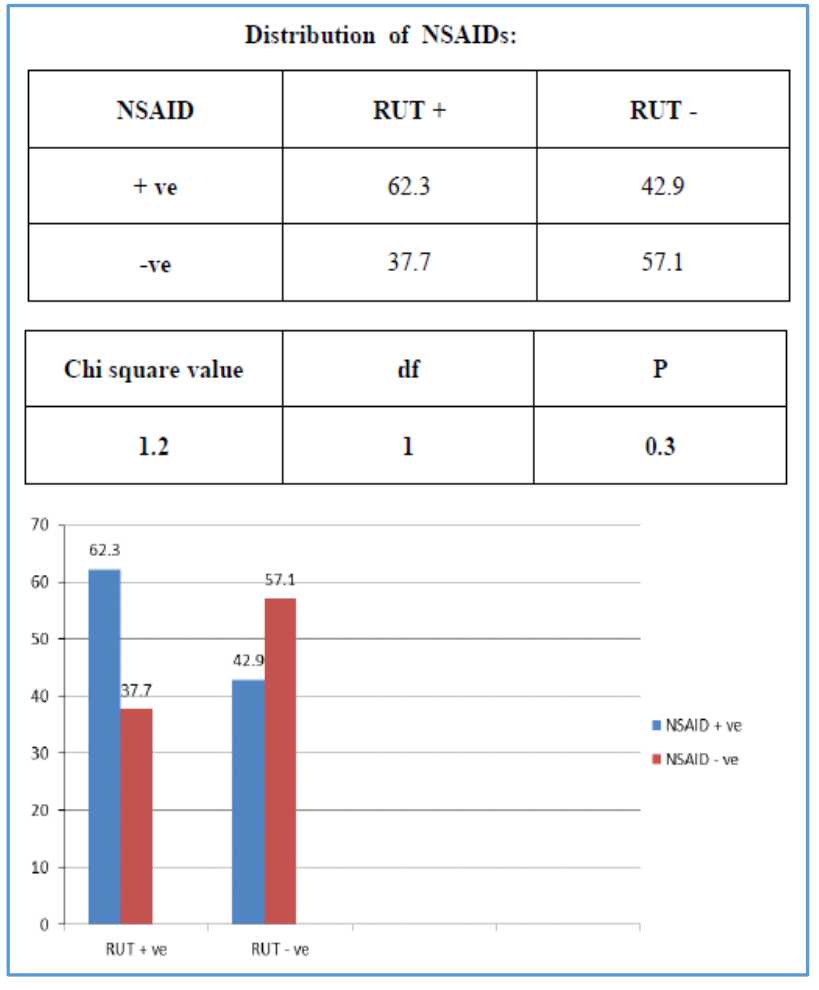
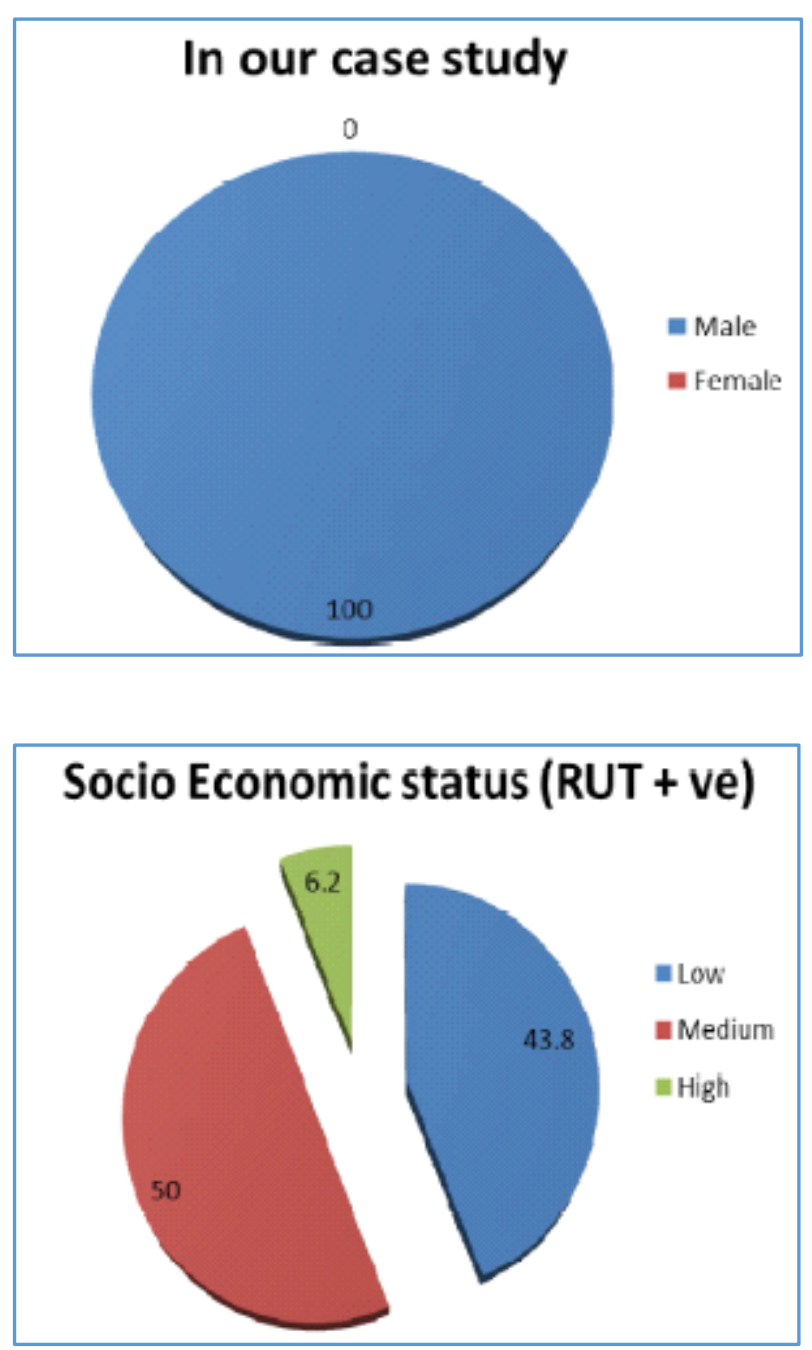

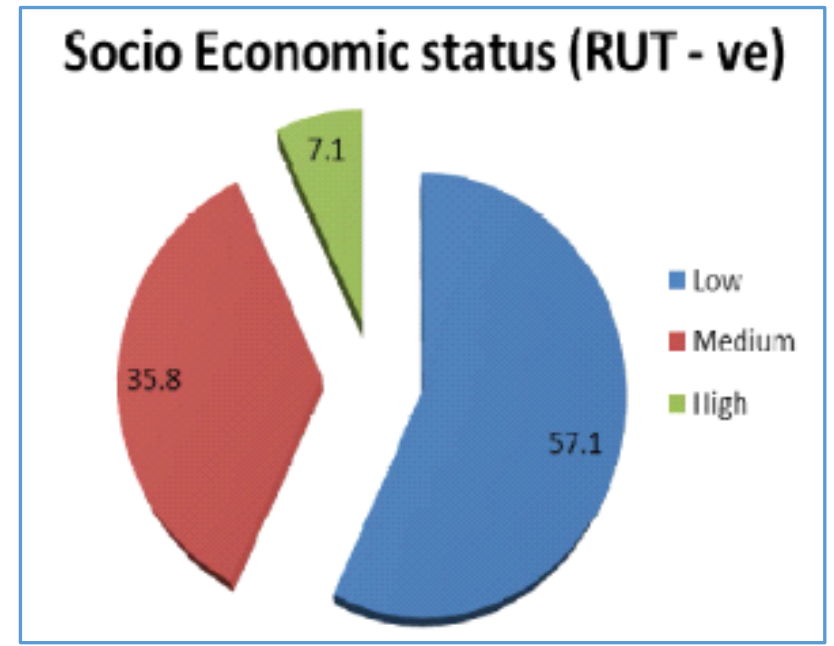

\begin{tabular}{|c|c|c|}
\hline \multicolumn{3}{|c}{ Distribution of Socioeconomic status: } \\
\hline SOCIO ECONOMIC STATUS & RUT + & RUT - \\
\hline L & 43.8 & 57.1 \\
\hline M & 50 & 35.8 \\
\hline H & 6.2 & 7.1 \\
\hline
\end{tabular}

\begin{tabular}{|c|c|c|}
\hline Chi square value & df & P \\
\hline 0.5 & 1 & 0.4 \\
\hline
\end{tabular}

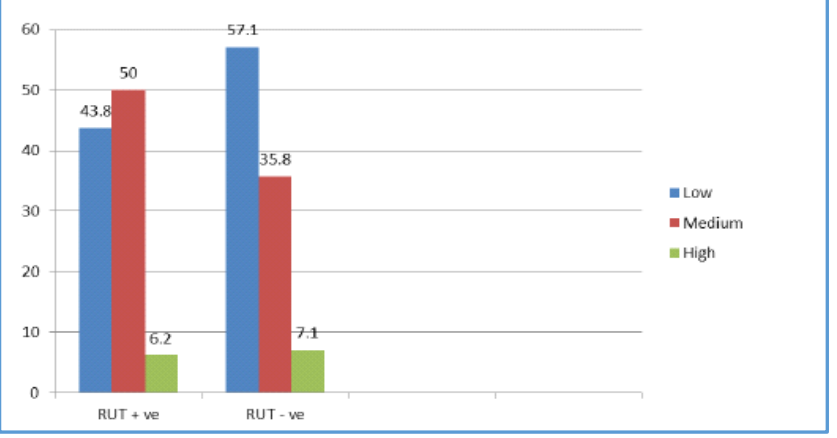

\section{DISCUSSION}

This is a prospective study of thirty cases of duodenal ulcer perforation admitted to Government Vellore Medical College \& Hospital during the period August 2014 to July 2015 to find out association of $\mathrm{H}$. pylori in the case of duodenal ulcer perforation. The aim of the study was to evaluate the incidence of Helicobacter pylori infection in perforated duodenal ulcer. ${ }^{5}$, 6] The pylori infection was found to be significantly higher in the younger age group with male preponderance. This prospective study examined a pathological aetiological agent namely Helicobacter pylori in perforated duodenal ulcer. ${ }^{[7,8]}$ This study indicates that patients with perforated ulcer were infected with $\mathrm{H}$. pylori more severely.[9,10] A close relationship was observed between the perforated ulcer and density of $\mathrm{H}$. pylori. Our study correlates with the findings of Yukihko Tokunaga et al. Similar studies were conducted by Minmamli N Isforaand et al, Department of Surgery and Pathology, Sisli Etfal Training Hospital, Istanbul Turkey. In the study conducted by Dept. of Surgery, Sisli Etfal Hospital, Istanbul, Turkey, patients who underwent surgery for a perforated 
duodenal ulcer in between January 94 to July 96 were studied. The study population consisted of 18 patients with a mean age of 32.7 years ( 21 to 48 years). Ulcer was excised with the pylori ring. All the patients were treated by bilateral truncal vagotomy and Weinberg pyloroplasty. Two biopsies were taken from the antral mucosa by endoscopic biopsy forceps.

The cut was then extended by about $2 \mathrm{~cm}$ on both the gastric and duodenal bulb. The defect was closed transversely. The ulcer specimen and the antral biopsies were fixed separately in $10 \%$ formalin solution and sent for histopathology. Specimens were stained with $\mathrm{H} \& \mathrm{E}$ stain and examined for $H$. pylori. $H$. pylori was found in the antral biopsies of 16 patients ( $88.8 \%$ ) and in the ulcer specimens (38.8\%). H. pylori was found in the mucosa and also extended through the wall of the ulcer.:[11,12] H. pylori was present at a high ratio in the antral biopsies of patients with duodenal ulcer perforation. In our series, a combination of RUT positivity and presence of organism on Genta staining was taken as positive for H. pylori. $53.3 \%$ of the patients tested positive for RUT $(10$ of strongly positive, 6 moderately positive), 46.7\% (14 of 30 patients) tested negative for RUT. The Istanbul study was based on the presence of H. pylori in biopsy specimens stained by H\&E stain.[13][14] In our study, all the cases are subjected to a preliminary RUT, whose sensitivity and specificity is of the order of $90-95 \%$. Later, all the biopsy specimens were subjected to Genta staining, which is a much more better staining procedure than H\&E staining, but also stains bacteria which are in low density, in a small biopsy specimen and in presence of abundant debris or mucus on the duodenal surface.[15].

\section{CONCLUSION}

Duodenal ulcer perforation was seen in the age group of 25 to 60 years of age (mean 44.6 years). All the patients were male, $83 \%$ were smokers, $73.3 \%$ were chronic alcoholics, $16 \%$ percent were addicted to pan chewing, $10 \%$ were addicted to gutkha chewing. $63.3 \%$ previous history of APD. $53.3 \%$ had the history of NSAID abuse, $16.6 \%$ were under antibiotic cover. Socioeconomic status of the patients was classified as High, Middle, Low. High group - 6.2\% RUT positive, Middle group - 50\% RUT positive, Low group - 43.8\% RUT positive. Forty five percent of patients were in treatment for APD. Most of the patients positive on rapid urease test positivity were also found positive for Genta staining. Our study showed about $53.3 \%$ patients in association with $\mathrm{H}$. pylori with duodenal ulcer perforation and the extensive usage of antibiotics and liberal utility of proton pump with or without combination of $\mathrm{H}_{2}$ receptor blockers shows $53.3 \%$ positivity and $46.7 \%$ negativity with the incidence of H. pylori in both RUT and HPE. The incidence of Helicobacter pylori in our case study is about $53.3 \%$. Even though, the total number of cases are less, $\mathrm{H}$. pylori correlates well with the cause for duodenal ulcer \& it can be considered as commonest cause. Hence, Helicobacter pylori should be eradicated using anti-H. pylori regimen in all cases of perforated duodenal ulcer. This study needs to be conducted further in large volume centres.

\section{REFERENCES}

1. Marshall BJ, Warren JR. Unidentified curved bacilli in the stomach of patients with gastritis and peptic ulceration. Lancet 1984;323(8390):1311-5.

2. Tovey FI, Hobsley M, Holton J. Helicobacter pylori virulence factors in duodenal ulceration: a primary cause or a secondary infection causing chronicity. World J Gastroenterol 2006;12(1):6-9.

3. Segal I, Ally R, Sitas F, et al. Co-Screening for primary biliary cirrhosis and coeliac disease. Helicobacter pylori: the African enigma. Gut 1998;43(2):300-1.

4. Boulos PB, Botha A, Hobsley M, et al. Possible absence of Helicobacter pylori in the early stages of duodenal ulceration. QJM 2002:95(11):749-52.

5. Pest P, Zarate J, Varsky C, et al. Helicobacter pylori in recently-diagnosed versus chronic duodenal ulcer. Acta Gastroeenterol Latinoam 1996;26(5):273-6.

6. Bytzer P, Teglbjaerg PS, Danish Ulcer Study Group. Helicobacter pylori-negative duodenal ulcers: prevalence, clinical characteristics and prognosis results from a randomized trial with 2 - years follow-up. Am J Gastroenterol 2001;96(5):1409-16.

7. Gdalevich M, Cohen D, Ashkenzi I, et al. Helicobacter pylori infection and subsequent peptic duodenal disease among young adults. Int J Epidemiol 2000;29(3):592-95.

8. Nomura A, Stemmermann GN, Chyou PH, et al. Helicobacter pylori infection and the risk for duodenal and gastric ulceration. Ann Intern Med 1994;120(12):977-81.

9. Schwarz K. Ueberpenetrierendemegen-und jejuna gashwure. Betirklinchir 1910;67:96-128.

10. Hobsley M, Whitfield PF. The likelihood of a disease in relation to the magnitude of a risk factor. The example of duodenal ulcer. Theoretical Surgery 1987:2:106-9.

11. Holcombe C. Helicobacter pylori: the Africa enigma. Gut 1992;33(4):429-31.

12. Holcombe C, Omatara BA, Eldridge J, et al. Helicobacter pylori, the most common bacterial infection in Africa: a random serological study. Am J gastroenterol 1992;87(1): 28-30.

13. Holcombe C, Omatara BA, Padonu MKO, et al. The prevalence of symptoms of dyspepsia in north eastern Nigeria: a random community based study. Trop Geog Med 1991;43(1-2):209-14.

14. Segal l, Ally R, Mitchell H. Helicobacter pylori - an African perspective. QJM 2001;94(10):561-5.

15. Tovey Fl, Hobsley M, Segal l, et al. Duodenal ulcer in South Africa: home-pounded versus milled maize. J Gastroenterol Hepatol 2005;20(7):1008-11. 